\title{
海産無脊椎動物の生殖腺の成熟に関する研究一VI.
}

\author{
イワガニの卵巣にみられる季節的変化* \\ 千葉 晃・本間義治 \\ (1971 年 9 月 20 日受理)
}

\begin{abstract}
Studies on Gonad Maturity in Some Marine Invertebrates-VII. Seasonal Changes in the Ovary of the Lined Shore Crab
\end{abstract}

Akira CHIBA** and Yoshiharu Honma**

\begin{abstract}
The present paper deals with the seasonal changes in the ovary of the lined shore crab, Pachygrapsus erassipes, known as a common crab which is widely distributed in the rocky beaches of the Japanese Islands. The animals used in the present study were collected along the coast of Niigata City facing the Japan Sea, and the period of collection extended from April to November, 1969. By means of histological examinations and gono-somatic index, the seasonal changes found in the ovary were classified into six stages. These are: growth stage (April), vitellogenetic stage (May to early July), premature and mature stages (middle to late July), spawning stage (late July), and recovery stage (August to November). A small number of sudanophilic bodies were detected in the ooplasm of the young oocyte and after that, the yolk globules began to be deposited in the entire ooplasm with accompanied growth of the ovum. In the spent individual, the ovary was characterized by a considerable number of the ovulation scars, residual ova and developing ovarian stroma, intermingled with each other. Subsequently, the ovary reached the recovery stage as revealed by the absorption of the residual yolk by the stromatous tissue and several kinds of leucocytes. As some of the spent females with developing embryos in their abdominal flap have another set of mature ovary, it is assumed that these crabs can spawn twice during a single breeding season.
\end{abstract}

カニ類の卵子形成過程や畉巣の発育過程を扱つた報文はいたつて少なく, BHATIA と NATH ${ }^{1)} か ゙$ Paratelphusa で卵黄の起源について観察したのや，CRONIN が Callinectes で畉巣の発達過程をみたもの，お よび ОTU゙ が内分泌学的立場からサワガニで卵形成過程を追跡したものなどがあるにすぎない。一方, 著 者らは，引続き海産無春推動物の成熟について基礎的研究を続けているが4 8)，上述したよらに，カ二類の 畉形成過程や卵巣の発達過程については，まだ十分研究されておらず，比較検討する例数の少ないことから， さらに資料を積む必要を認めた。そこで，前報と同じイワガニの長期間にわたる材料に基づいて卵巣を組織 学的に観察したところ, 卵子の発育相に季節的变化が認められたので報告する。

本交を稿するにあたり，討論をいただいた福井県水産試験場の今敒技師，および採集に協力いただいた新 㵧大学理学部付属佐渡臨海実験所の北見健彦氏比謝意を表する。

材料および方法

供試材料のイワガニ Pachygrapsus crassipes は, 1969 年 4 月から 11 月にわたり, 新潟市の寄居浜海

* 新潟大学理学部付属佐渡臨海実䍄所業續

** 新潟大学理学部生物学教室 (Dept. Biol., Fac. Sci., Niigata Univ., Niigata, Japan) 
岸の突堤から採集した。採集は原則として月 2 回（合計 15 回）おこない，甲幅 $15 \mathrm{~mm}$ 以上の雌を約 90 個 体得た。前報したよらに, 日本海沿岸に淤る冬季の荒天のため, 12 月から 3 月にかけては採集できなか

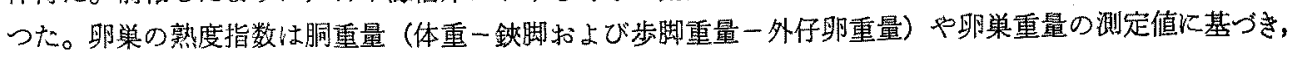
次式から求めた。

(畉巣重量/胴重量) $\times 100$

背甲下から摘出した畉巣は海水で調合したプアン氏液やブフン・アレン氏液の汪かに，チアッチオ氏液, カルノア氏夜怙よびボーディフン氏液で固定し，常法に従つて $6 \sim 8 \mu$ のパラフィン切片を作つた。染色に はハイデンハイン氏の鉄へマトキシリン・ライトグリーン, デラフィールド氏のーマトキシリン・エオシン, ハイデンハイン氏のアザン三重染色, メチルグリーン・ピロニン, アルデヒドパラローズアニリン・ライト グリーン ( $\mathrm{AF}$ 変法)、ズダンブラックB・フロキシンを用い, PAS 反応も試みて鏡検した。

結果

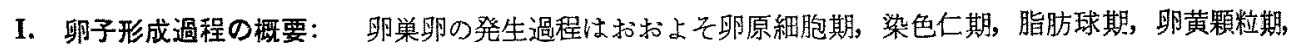
畉黄球期 I, 即黄球期 II, 前成熟期括よび成熟期の 8 段階に分けられる。

(1)畍原細胞期：期原細胞は径 $8 \mu$ の球形の核を有し，細胞質はいたつて薄く，色素非好性である。静止 期の核ではクロマチンが網目を呈して一様に分布している。卵原細胞は数個集つて，若い卵母細胞と共に卵 紧中央部に增殖中心を形成しており，有系分裂がほぼ周年にわたつて観察できる(P1. I一Fig. 1)。(2)染色 仁期：この時期になるとクロマチンは核膜部から凝縮をはじめ，やがて星形の染色糸塊となつて核の一端 に現われる(接合期)。長い休止期を経て, 染色糸塊は不規則形をしたクロマチンの小塊となつて, 核膜付近 に斑点状汇分布する。このころ, 明るい核の中央部には1個の染色仁が現われ, 卵の発育に伴つて成長を続

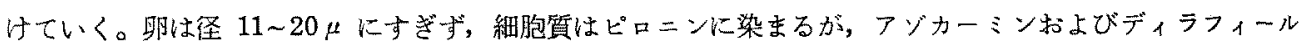
ド氏のへマトキシリンとの親和性はまだ低い（P1. I一Fig. 2)。(3)脂肪球期：卵細胞質の增加により，那膲 は $20 \mu$ 加 $60 \mu$ に達する。クロマチンは顆粒状ないしは細系状で, 核内に医活一様に分布している。邲 細胞質は均質で前段階のもの上りへマトキシリンやアン゙カーミンに好染されているが，フルデヒド・パラロ ーズアニリンとの親和力やPAS反応恬弱い。チフッチオ氏液で固定した場合, 細胞質中には, 径 5 10 $\mu$ の ズダンブラック B 好性の脂肪球が 1 数個認められ，高倍率で観察すると桑荚状にみえることがある (P1. I 一Fig. 3)。しかし，ブアン氏液で固定したものでは空胞かまたは不規則形の芯を有する空胞梯構造として諗 められ，芯部はフニリンブルー好性で，AFやPAS 反応にも陽性を示した (PI. I一Fig. 4)。卵母細胞性拉 のおの一層の扁平な汇胞膜によつて包まれている。(4) 卵黄顆粒期: この時期の卵は発育して径 $60 \sim 90 \mu$ 飞達する。先述の空胞槏構造は表層部に移動し, それと相前後して細胞質全体に小空胞が多数散在し, 蜂简 状を呈するようになる。(P1. I-Figs. 5, 6)。これらの小空胞は, 前述のチアッチオ固定, ズダンブラックB 染色により脂肪性の畍黄顆粒であることを確めた（Pl. I-Fig. 7)。卵の成長に伴い，この脂肪性の畉黄顆 粒はPAS 反応湯性を示し，アニリンブルーやオレンジGでる染色され，卵黄形成は遠心的に進む (P1. I 一Fig. 6)。畍黄形成に先だち細胞質の色素親和性は変化してアニリンブルー好性㧍よびへマトキシリン非 好性となり，PAS 反応炕より紫色を呈する。(5)卵黄球期 I：卵は径 $100 \sim 200 \mu$ を計り, 球形の核はこれ までと大差なく明嘹に認められ，汇胞膜も以前とか子りない。畉黄顆粒は成長して畉黄球となり，表層部り あのはど大形である。これらはアゾカーミンや鉄へマトキシリンで好染され，PAS 反応には紅色を示す。 畉表層部には空胞がかなり整然とならび，これらの内部にはアニリンブルー弱陽性の膠質状物質が满たされ

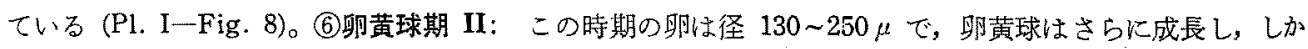
毛融合しはじめる。核は以前とかわらず即の中心部にみられるが，核膜はしたいに波打ち不明瞭となる。内 部のクロマチンは均䝷になり，染色仁との境界が不明嘹となつて，射径 $230 \mu$ 前後のものでは染色代諗

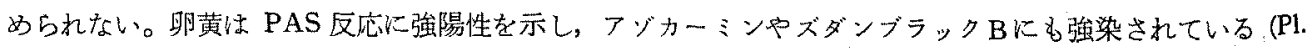
I-Figs. 9，10）。瞚黄に混じつて空胞が散在している。卵膜はごく薄いが依然として明瞭である。(7)前成熟 
期：卵径は $250 \sim 300 \mu$ に達し，互いに押し合つて外形がゆがんでいることが多い。卵黄は融合し続け，不 規則な多面体となるが，空胞はこれまでと大差がない。沪胞細胞の核は凝縮し，さらに扇平化して不明瞭と なる。細胞質は卵の中心部にかろらじて認められるにすぎず, 核の存在は確認できなかつた(P1. I一Fig. 11)。

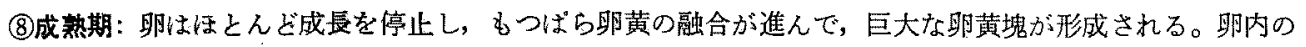
空胞や緗胞質の状態は前成熟期のものと大差がみられず，核も確認できなかた。沪胞膜は痕跡的にまで扁平 化しており，畉 1 個 1 個の区別はさらに困難になる(P1. I一Fig. 12)。なお，完熟卵については観察する機 会が得られなかつた。

\section{Stage of growing ovum}

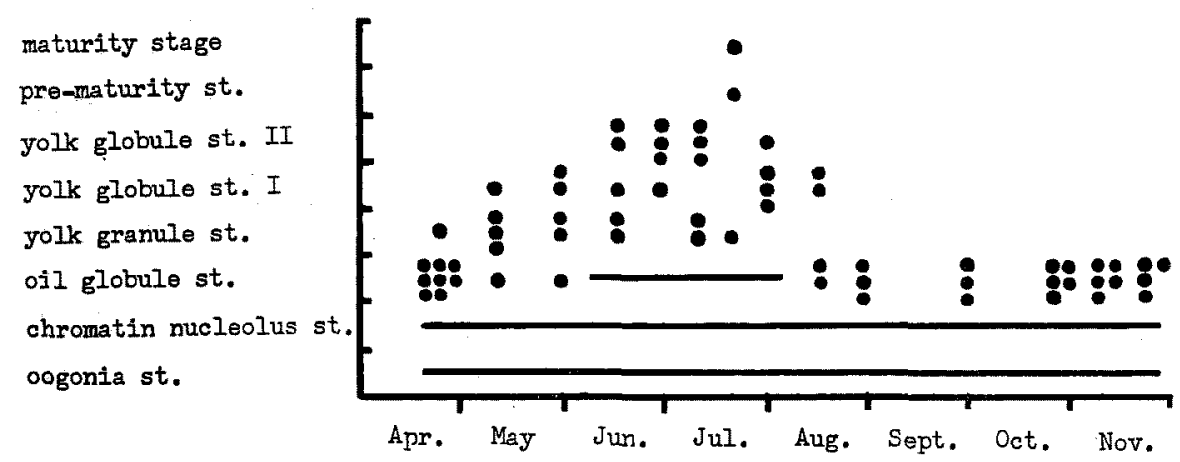

Fig. 1. Seasonal change of the developing ovarian ova in the lined shore crab.

II. 卵䉾にみられた季節的变化：卵巣の発達過程を組織学的観察, 熟度指数括上び生鮮時に括ける外

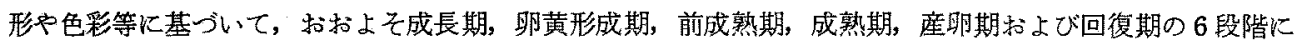
分けて検索を進めた。またこれら卵巣卵の発青過程を季節的にプロットしてみた（Fig. 1)。

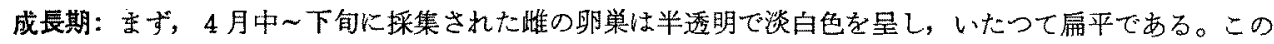

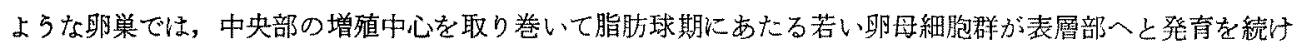
ている(P1. II-Fig. 1)。卵黄形成期：5月に検したものでは卵母細胞の多くが，卵黄顆粒期に達しておら， なかには畉黄球期 I の眼を有する個体るみられた(P1.II一Fig.2)。この時期の邲巣は，したいに黄色から橙 黄色に色ずくが，熟度指数はまだ低く0.5 2.0 にすぎない。6月には畉果中央部の若い卵群と，やがて成

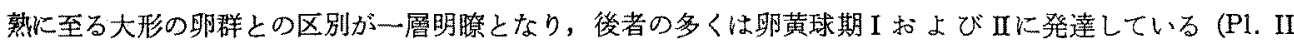
一Fig. 3)。即巣は橙色ないし橙褐色を呈して和り，熟度指数は $2.0 \sim 10.0$ と高くなつている。また，下旬 にはすでに産畉を終光たるのるみらけられた。7月初〜中旬では，大形の雌（甲幅 $25 \mathrm{~mm}$ 以上）小小形の

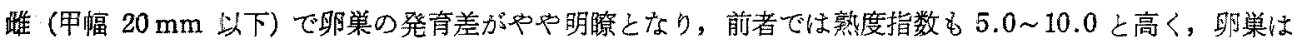
肥厚して中腸腺上に大い張り出しているが，後者では甽黄形成がはじまつたばかりで，低い状態のものが

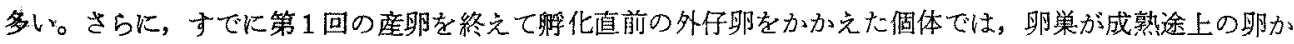
らなつており，本夏内での第 2 回目の産鲡が予想された。前成熟期，成熟期：7月中〜下旬に検した個体の 卵单は背甲下に大きく隆起して卵粒む1 個 1 個区別でき，熟度指数は 10.0〜20.0 と頂点に達している。こ のころの卵巣は紫褐色で，前成熟期の卵がたは成熟期の卵からなり，未熟な卵群はこれらの卵群の間に樹 枝状に連なり存在しているにすぎない(P1. II-Figs. 3，4)。産卵期：8月中旬には注とんどの個体が産畉

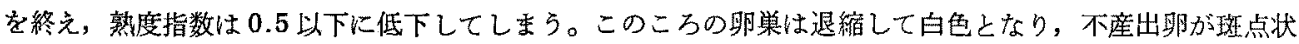

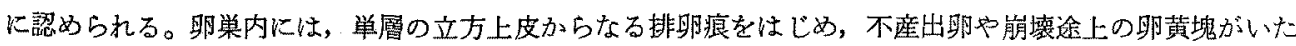
るところにみられるほか，成熟に至らなかつた若い即拇細胞が入り乱れて基質成分中に散在している（P1． II-Fig. 5)。注目すべきは，不産出畉や崩壊途上の畉黄塊中に，沪胞細胞や白血球が侵入して食作用を営儿 
でいることである。回復期：9月から11月にかけては, 産卵直後飞認められた排眼痕や不産出畉は消失し てし亡う。残存卵黄の小塊の恋わりは沪胞細胞が何層にも同心円孤老描いて取り巻き，中心部には活発な食 作用の結果を思わせるよらな空胞が形成されたり, 白血球の侵入も認められた (P1. II-Fig. 6)。線維性結 合織はさらに発達し, 各種白血球の增加と血管の侵入が影著である。なお，增殖中心部では，これまでとか わらず莭原細胞の分裂が観察された。

\section{考察}

イワガ二の卵形成や卵巣の発育過程について，光学影微鏡的に観察を進めてみたが，まボ細胞レベル（微 細構造) で不明な点が多い。BHATIA と NATH ${ }^{11}$ にると, 淡水産の Paratelphusa では, 細胞質中湤 出された物質やゴルジ体が甽黄形成に大きな役割を果すことが知られている。しかし，イワガニでは各種 細胞内小器官や封入体について詳細な追跡をしなかつたので，卵黄形成機構に関しては明確でない。たた本

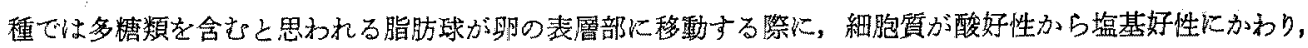

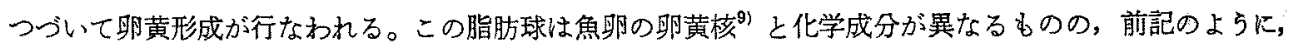
構造や行動がそれに似ているふしもみられ，卵黄形成に何らかの役割を持つるのと推察される。イワが二の 卵黄塊は, 組織化学的検出法に上れば, 脂質と炭水化物を含むるのと考えられるが，前成熟期の卵でみられ た空胞についてはその性状を明らができなかつた。汇胞細胞層が卯の栄養物質供給に重要な役割を果すこ

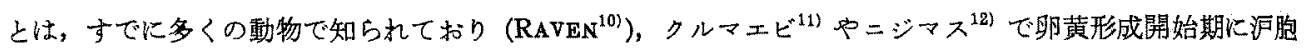
上皮が肥厚するといら観察結果もこの事実の形態学的裹づとして興味深い。しかし, 本種では卵形成過程

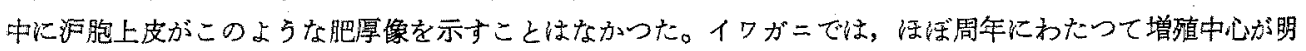

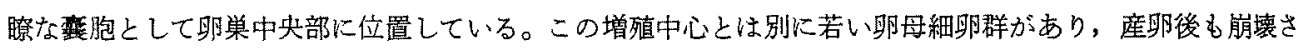
れず存続している。したがつて，12月から3月にかけて経産卵巣の内部が整理し終ると，これら若い卵 母細胞群は，新たに增殖した卵群と共に翌夏本で発育を続け，成熟に至るものと考えられる。このよらな

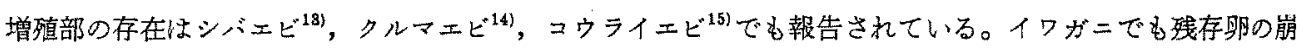
壊吸収には，ズワイガニ゙) やイボニジ)などで記載されていると同様に，沪胞細胞が重要な役割を果すが， イワガニでみられだ白血球の增加や沪胞細胞が同心円状のラメラ構造をとることについて，後二者では触れ ていない。

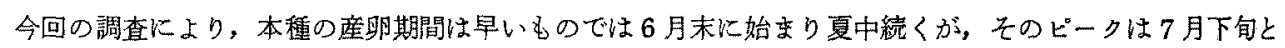
目された。この期間中，同一個体が少なくとも2回産卵寸るらしいことが明らがなつたが，この上らな習 性は Mennipe $e^{16)}$ でも知られて扣り，第1回目之第2回目の産㽗間隔は約 8 日間と報じられている。しかし，

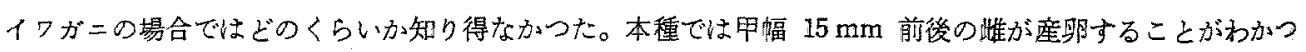

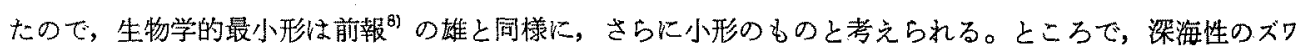
イガニ ${ }^{5)}$ では初産後 1 年半も执くれて第 2 回目の産畉が特こなわれるらしいが, 本種では初産が二の大きさ む確めていないので, 産卵期のずれを Mennipe ${ }^{16)}$ を含めて, いきなり生息環境や生活形の相違に結びつけ ることはできない。

イワガニの生殖については, まだ研究が緒についたばかりであり，今後は脱皮々産卵の関係をはじめ，上 述したいくつかの不明な点を解明していきたい。

要 約

新潟市海岸産のイワガニの 4 月から 11 月にわたる材料に基づいて, 卵形成過程放よび卵巣の発育過程を 組織学的に観察した。その結果, 卵巣畉の発達段階には季節的变化方認められ，括括よそ4月の成長期， 5 月から 7 月初旬にわたる畍黄形成期，7月中〜下旬の前成熱期和よび成熟期，7月下旬にピークがみられる 座卵期，おさび，8月下旬以降の長期沈わたる回復期の 6 段階に分けられる。

産卵は，早い個体では 6 月下旬からはじまり夏中続き，その間に同一個体が少なくとも 2 回産畉するよう 
である。增殖中心は卵巣中央部にほぼ周年にわたつてみられ，例年若い卵が産生されている。

卵黄形成は 5 月頃から始まり，はじめ脂質を多く含む卵黄顆粒が形成され，成長と共に多楉類が加かつて 成熟期では巨大な卵黄塊となる。沪胞細胞や畉巣基質成分は，不産出卵や残存卵黄の崩壊および四収に役割 を果し，回復期には各種白血球の增加や線維性結合織の発達が影著である。

\section{文献}

1) D. R. BHatia and V. NATH: Quart. J. Micr. Sci., 74, 669 701 (1931).

2) L. E. Cronin: M.S. thesis, Univ. Md., 1 37 (1942).

3) T. OTU: Embryologia, 8, 1 20 (1963).

4) 今敒・本間義治・村川新十郎： 本誌, 32, 484 491 (1966).

5）今敒・本間義治：本誌，36，1021 1027 (1970 a).

6) 今敒・本間義治：本誌，36, 1028 1033 (1970 b).

7) 千葉 晃・本間義治： 本誌，37，699 706 (1971).

8) 千葉 晃・本䦓義治：本誌，38，317 323 (1972).

9) 山本喜一郎：細胞化学シンポ, 8, 119 134 (1958).

10) C. P. Raven: Oogenesis, 1 274 (1961), Pergamon Press, Oxford.

11）福井県水産試跧場：福井水試報告，45，24２8(1970).

12) 山本喜一郎・太田 整・高野和則・石川徹二：本誌, 31, 123 132 (1964).

13) T. Y. LEE: Pub. Haeundae Mar. Lab.,1, 19 28 (1968).

14) T. Y. LEE and B. D. LeE: Pub. Mar. Lab., Pusan Fish. Coll., 3, 45 52 (1970) in Korean. with English summary.

15）岡 正雄： 長崎大水産学部研報, 23, 43 56 (1967).

16) R. Binfold: J. Morph., 24, 147 203 (1913). 


\section{Plate I.}

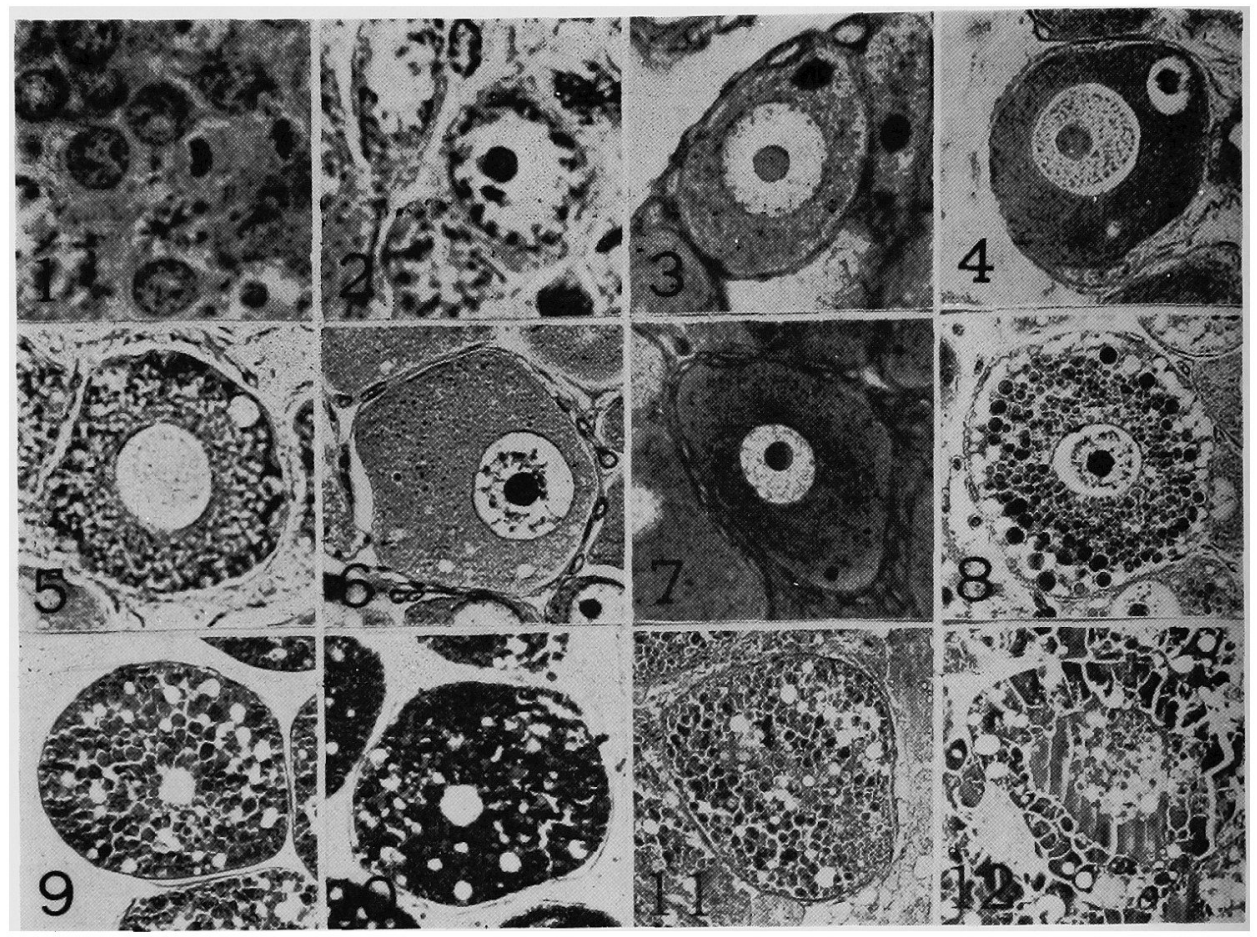

Plate I.

Fig. 1. A cluster of the oogonia just in the mitotic division. Bouin's fixative, hematoxylin-eosin stain. $\times 800$

Fig. 2. The younger oocytes in the chromation nucleolus stage. Bouin's fixative, azan stain. $\times 1000$

Fig. 3. The oocytes in the oil globule stage showing the sudanophilic body in the ooplasm. Ciaccio's fixative, sudan black B stain. $\times 520$

Fig. 4. By means of Bouin's fixative, the oil globules are demonstrated to be the vacuoles, some of which contain the cored material. Bouin's fixative, PAS-orange G stain. $\times 520$

Fig. 5. In the early yolk granule stage, the ovum is filled with the vesicular structures derived from the yolk granules of adipose nature. Bouin's fixative, PAS-orange G stain. $\times 320$

Fig. 6. The major part of the ovum containing the basophile ooplasm is occupied with a lot of yolk granules. Bouin's fixative, azan stain. $\times 340$

Fig. 7. A number of yolk granules containing the fatty substance are demonstrated. Ciaccio's fixative, sudan black $B$ stain. $\times 430$

Fig. 8. In the yolk globule stage $\mathrm{I}$, two kinds of yolk globules are distinguished: one is the oil globules located in the peripheral or cortical region, and another is the PAS-positive yolk ones in the central or perinuclear region. Bouin's fixative, azan stain. $\times 220$

Fig. 9. In the yolk globule stage II, the globule, polygonal in shape, is positive strongly with PAS reaction. Ciaccio's fixative, PAS-orange G stain. $\times 100$

Fig. 10. The dark stained yolk globules as revealed by sudan black B. Several vacuoles of unknown derivatives are detected throughout the egg body. Ciaccio's fixative, sudan black B stain. $\times 110$

Fig. 11. Due to a large mass of the yolk, the germinal vesicle is difficult to recognize. Bouin's fixative, azan stain. $\times 100$

Fig. 12. The egg close to the ripe stage. As a result of fusion of the yolk globules, a huge yolk mass was taken place. Bouin's fixative, PAS-orange G stain. $\times 100$ 


\section{Plate II.}

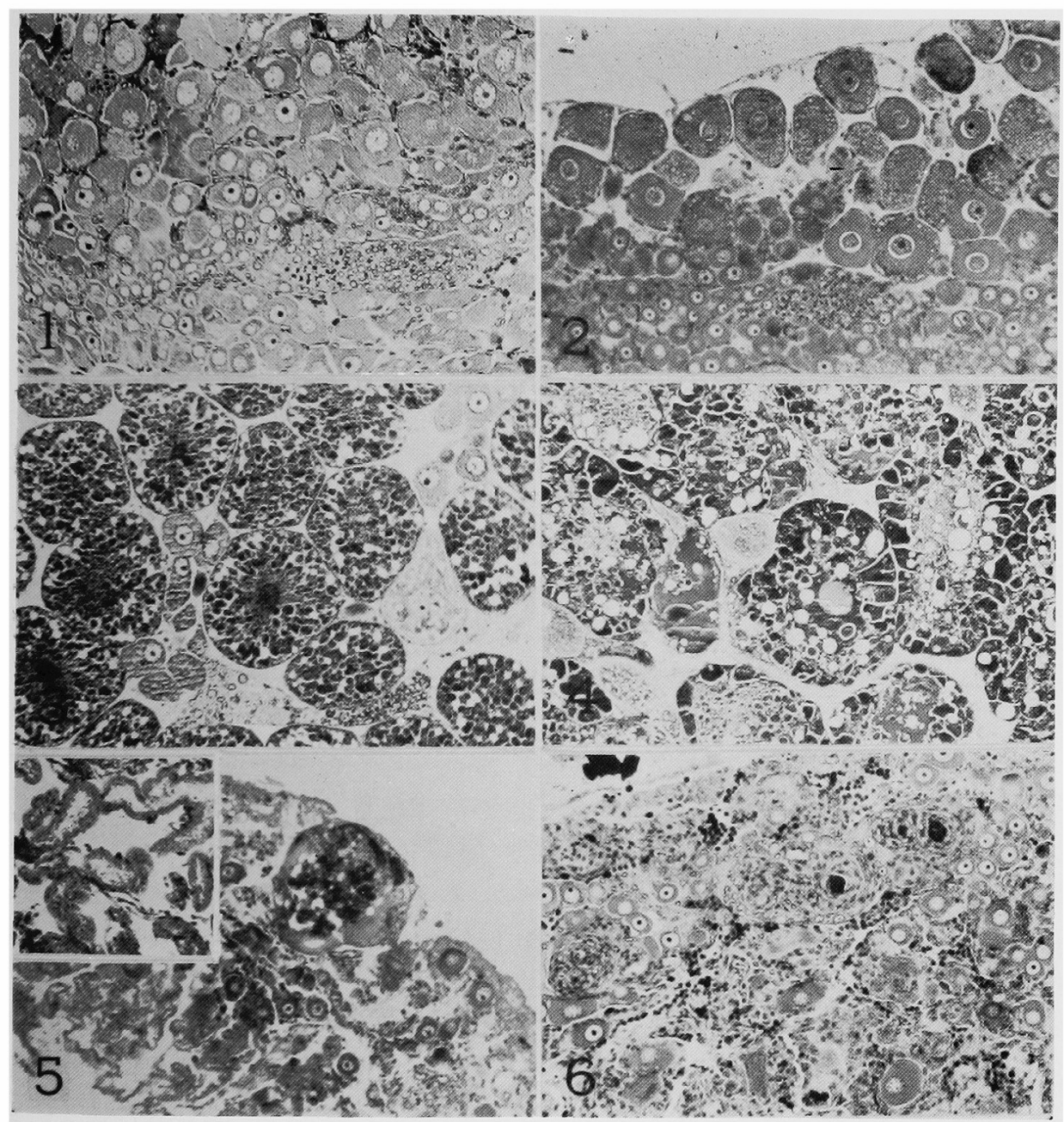

Plate II.

Fig. 1. In April, the ovary is filled with the growing oocytes of young stage. The germ center consisting of the oogonia under the mitotic division is also demonstrated in this picture. Bouin's fixative, azan stain. $\times 100$

Fig. 2. A part of the ovary in the early stage of yolk formation in May. Bouin's fixative, azan stain. $\times 100$

Fig. 3. In early summer, the germ center and a small number of younger oocytes still remained among the well-developed oocytes. Bouin's fixative, azan stain. $\times 100$

Fig. 4. Cress section of a part of the ovary reaching close to the ripe stage in July. Bouin's fixative, PAS-orange G stain. $\times 100$

Fig. 5. The spent ovary in August is characterized by the existence of unspawned eggs and ovulation scars. Inset indicates the ovulation scars. Bouin's fixative, azan stain. $\times 100$

Fig. 6. A part of the ovary in the recovery stage of autumnal season. A pronounced development of the stromatous tissues and leucocytes are noticed. Bouin's fixative, iron hematoxylin-light green stain. $\times 100$ 